UDC 811.111'322.4

DOI https://doi.org/10.32838/2710-4656/2021.6-1/21

Karachun Yu. G.

National Technical University of Ukraine "Igor Sikorsky Kyiv Polytechnic Institute"

Borkovska I. P.

National Technical University of Ukraine "Igor Sikorsky Kyiv Polytechnic Institute"

\title{
ENGLISH SCIENTIFIC AND TECHNICAL TEXTS IN MODERN LINGUISTIC STUDIES
}

The scientific article is devoted to the consideration of the main categories of English modern scientific and technical text. Thus today, in the era of information technology and scientific discoveries, it is extremely important to transfer successfully the results of scientific achievements to the public, and this happens often through the scientific and technical literature. Therefore, it is necessary to identify the concept of scientific and technical text in detail, to indicate the main approaches within which the scientific and technical text is considered and to define its main categories. In the process of the research it was found out that the scientific and technical text was considered within socio-historical, structural and semantic, functional and semantic, socio-communicative, pragmatic and cognitive approaches. The first defines the text as a product of written activity which reflects the results of scientific research by communities in different epochs of their existence. Within the structural and semantic approach, the text is considered as a consistent semantic unity of phrases; functional and semantic characterizes the text as a complete semantic unity, which is based on the semantic and functional relationship that exists between the elements of such a text. Socio-communicative defines the text as a product-mediator between communicators, which transmits information for discussing; within the pragmatic approach, the text is a means of influencing the recipient of information taking into account certain pragmatic factors, namely the target audience, its age, social status, education, etc., and cognitive that helps to understand the text as a way of learning under the influence of the above pragmatic factors. It is determined that the functional approach has become a prerequisite for the formation of text categories, among the main ones are cohesion, integrity (coherence), informativeness (communicativeness), articulation (structure), completeness, pragmatism. Among the main linguistic factors that form the scientific and technical text is the use of terminological vocabulary (simple, compound, compound terms, phrases, terms, metaphors, abbreviations), joining elements. The syntactic level is represented by simple indefinite-personal, impersonal, infinitive, nominative constructions, compound syntagms with different types of communication (coherence or subordination). We consider unambiguity (accuracy) as the main extralinguistic dominants of scientific and technical literature; logic (sequence) of teaching the material; clarity (accessibility); provability (persuasiveness); conciseness (brevity); expressiveness; scientific novelty, monologue nature of such texts.

Key words: scientific and technical text, text categories, linguistic feature, extralinguistic factor, term, syntactic structure.

Formulation of the problem. Scientific and technical texts are formed during the process of scientific research in deferent technical spheres after making the breakthrough in it. They are considered to be one of the main solid sources of information that can transmit the material and provide further communication between scholars. The topicality of the research is in analyzing the notion of scientific and technical text, examining main approaches in studding this linguistic phenomenon, pointing out main text categories.

Analysis of the latest researches and publications. Scientific and technical text is studied by functional stylistics, which studies the features of language norms in accordance with the scientific style; linguistic pragmatics, which analyzes the purpose of communication participants, as well as a person's attitude to their own and others' speech; linguistics of the text, which investigates the norms of construction, structural and stylistic features of the scientific and technical text; psycholinguistics, which clarifies the processes of language creativity, perception and formation of speech and the correlation of these processes with the language system. Over the past years, both Ukrainian and foreign linguists have studied scientific and technical texts in different 
aspects, the main works are: E. S. Aznaurova, F. S. Bacevich, I. A. Bekhta, M. P. Brandes, Dzh. Braun, N. S. Valgina, A. Vezhbitska, T. V. Drozdova, N. I. Enkvist, O. V. Yemets, A. Zagnitko, T. M. Zuenko, N. G. Ishchenko, M. Kauthard, V. V. Kozlovskij, N. K. Kravchenko, V. A. Kukharenko, T. B. Maslova, A. S. Matveeva, I L. Naumenko, T. V. Radzievska, O. O. Selivanova, Z. Ya. Turaeva, O. J. Sheigal etc.

Formulation of goal and tasks of the research.

The goal of the research is to analyze scientific and technical texts in modern English. Formulated object led to the task solving, such as:

- define the meaning of the concept "scientific and technical text";

- analyze main approaches in the process of studding modern scientific and technical texts;

- focus on main text categories, linguistic and extralinguistic factors that form the text.

Object of the research - scientific and technical texts in modern English.

The material of the research are scientific and technical literature (15 manuals, 9725 pages), 15 scientific articles (160 pages), 15 technical contracts (70 pages) and 15 technical instructions (341 pages).

\section{Main material.}

Analysis of general theoretical material showed that scientists considered the scientific and technical text from the standpoint of:

- socio-historical approach, according to which the scientific and technical text is defined as a written product that represents the results of intellectual and scientific activities of society in different eras of its existence [1];

- structural-semantic approach, according to which the scientific and technical text is a statement that is characterized by a set of consistently interconnected phrases and completeness [2]. According to A. Zagnitko the text is always semantically completed and comprehensively understandable, otherwise it loses its communicative sufficiency and value [7, p. 34]

- functional-semantic approach, according to which the scientific and technical text is considered as a complete semantic unity due to the semantic and functional ratio of the elements of the text [2];

- socio-communicative approach, according to which the scientific and technical text is defined as a compound communicative mechanism, where the text is a product of scientific activity and a mediator of speech (communicative) activity between the speaker and the recipient of information [3];

- pragmatic approach, according to which the scientific and technical text is considered as a means of socio-psychological influence on the recipient, because according to O. V. Yemets [6], N.G.Ishchenko[8],Z.Ya. Turaeva[10] communication in the scientific environment and beyond is carried out mainly through the text, which is able to some extent to influence the consciousness of the recipient and motivate him to certain actions;

- cognitive approach, according to which the scientific and technical text is considered as a way of cognition under the influence of certain sociopragmatic factors [5];

Having considered and analyzed the multifaceted interpretation of the scientific and technical text from the approaches mentioned above, it was made an attempt to generalize this information in own definition of this concept.

Thus, the scientific and technical text is an ordered structural and semantic, compositional and stylistic, functional and pragmatic unity, united by different types of lexical, logical, grammatical connections, which represents the results of human scientific activity, serves as a means of transmitting scientific information, which are implemented in accordance with the motive, purpose, chosen topic, idea and audience etc.

The functional approach to the study of scientific and technical text has led to the actualization of the problem of text categories, the main are connectivity (cohesion), integrity (coherence), informativeness (communicativeness), articulation (structure), completeness, pragmatism, because such categories allow us to consider the scientific and technical text as a unity [8].

We propose to consider the main linguistic and extralinguistic factors that form the scientific and technical text of modern English.

The linguistic factors include:

- wide use of terminological units: simple, compound and abbreviated, terms-metaphors, compound syntagms, language clichés, etc.;

- deployed system of connecting elements (comparison or contrast).

At the syntactic level, language factors are implemented by using: syntactic structures, which are characterized by completeness of design, indefinitepersonal, impersonal, nominative, infinitive syntactic constructions; compound syntagms with subordinate relations, conditional syntactic constructions.

As mentioned above, the texts of scientific style are characterized by frequent use of terminological vocabulary. Among the terminological vocabulary of scientific style, we observe the use of metaphorical terms, in the structure of which one or more word- 
forming components can be expressively colored, which is caused by the author's desire to convincingly and accurately convey information to the public: toothvoltage, butterfly-antenna, pig-tail, bottle-neck.

Each of the borrowed bases of compound noun-terms, which is in the preposition, can have an enhanced semantic load and indicate the functional characteristics of the depicted reality, say the base micro- ( $\mu 1 \kappa \rho o ́ s)$, which translated from Greek means "small", nano- (vóvos), which in Greek means "dwarf, tiny", macro- ( $\mu \alpha \kappa \rho o ́ s)$, which in Greek means "large", "large-scale" characterize the depicted reality from the standpoint of size, multi(multum), translated from Latin means "reusability", "abundance", indicates the multifunctionality of the objects that are marked, and so on: monopod, microengine, polybagger.

A feature of compound term-metaphors, which are formed by word formation, is the presence in the multicomponent terminological unit of common vocabulary components, the meaning of which is transferred to the whole terminological unit on the basis of similarity between them, including similarity of size, shape, consistency, appearance, etc. by functional analogy (functional purpose).

Joining elements include words and phrases: as a sign of a modal assessment of confidence or uncertainty, prediction, possibility or impossibility or doubt: indeed, however; which indicate to whom the opinion belongs: due to; that help to organize thoughts and connect them with each other: therefore, consequently, firstly, moreover, furthermore.

The syntactic features of the linguistic design of scientific style texts include the syntactic completeness of expression, the use of simple indefinite-personal or impersonal syntactic structures of narrative nature with the direct order of words of the passive state. Example: Rotary evaporators (also called "rotavaps") are used to remove solvents from reaction mixtures and can accommodate volumes as large as 3 liters. It should be noted the imperative and persuasive nature of the syntactic structures of certain genres of scientific style texts, such as instructions or contracts, which induce action to carry out an order, desire, request, permission, advice, or prohibition, and so on. Example: When clean, maintain and repair the generator sets, please shut down the generator set and cut off the connection of negative polar of the battery or dismantle battery connecting cable, and place warning label at the relative place so that to avoid accident. The basis of the syntactic level are compound syntactic constructions with subordination expressed by contracted conditional sentences. Example: If the dishwasher gets rusty, you can remove it by putting two tablespoons of citric acid in the detergent compartment and running a Normal program.

Within the scientific style there is a presentation of research results to society obtained in the process of scientific research: presentation of material, systematization of previous knowledge, notification of new research results, classification and systematization of knowledge according to certain criteria, proof or refutation of theories, substantiation of hypotheses, analysis and explanation, processes of a certain branch of science and technology, etc.

O. M. Semenog mentioned the observance of certain principles in the formation of texts of scientific style:

- the principle of content saturation, which is characterized by the presence in scientific and technical texts of professionally oriented information, the main task of which is to provide the recipient with the necessary knowledge in the learning process; the text must be lexically filled, and the syntactic structures must be correctly constructed;

- the principle of professional significance, which is that each scientific and technical text must contain professional information focused on a particular field of science and technology;

- the principle of scientific informativeness, which implements the presence in the scientific and technical text of important, important, modern information, the main task of which is to provide the recipient with the necessary knowledge, results, assessment and generalization of a phenomenon or process, in particular in electrical engineering;

- the principle of novelty, which determines the availability of new sound theoretical or practical research set out in scientific and technical texts, which will be a significant contribution to further scientific research;

- the principle of semantic completeness, which is characterized by the completeness of the presented material; disclosure, analysis, justification and generalization of tasks;

- the principle of accessibility, characterized by a significant percentage of perception of information by the reader or listener, a high level of intelligibility of the content of the text by the addressee;

- the principle of intertextuality, which provides for the possibility of reproduction, reflection in the new scientific and technical text of elements of previous scientific works in the form of citations, references, comments, etc.

Based on this, the main extralinguistic dominants of the scientific style are considered unambiguous (accuracy); logical sequence of presentation of the material; clarity (accessibility); provability 
(persuasiveness); conciseness (brevity); scientific novelty, monologue $[8$, p. $79 ; 9$, p. 29].

Unambiguity (accuracy) is considered to be the most important factor in the formation of scientific style, because the texts of this style are designed to act as a channel of communication between scientists and society, such a text serves as a means of transmitting coded information obtained from scientific research and accurate delivery to society. The degree of accuracy depends on the author's ability to select exactly those lexical units that would most accurately convey, describe and characterize the depicted concept, phenomenon, device, device or action.

Accuracy (unambiguity) is realized by frequent use in the scientific and technical text of special vocabulary (simple, compound terms, phrases, compound syntagms, abbreviated structures or abbreviations, etc.)

The author realizes the logic (sequence) of the text of scientific style in the consistent and reasoned delivery to society of knowledge, statements, results of scientific research in accordance with the norms of language and speech. Before publishing the results of scientific research, the author performs a number of necessary actions:

- analyzes, systematizes, unifies the results of scientific research by consistently considering the stages of research, establishing the order of actions, based on previous data and developing the next;

- seeks the necessary lexical units with which it would be possible to more accurately convey what needs to be explained or depicted in the text in order to achieve semantic coherence of speech, using direct word order, interjections and phrases, clichés that express the logic of thinking and indicate on the connection between parts of the whole text.

The accuracy and logic material provide clarity (accessibility) of the text of scientific style. The sign of comprehensibility is realized through the sequence of the material, through the logical development of ideas, through the use of terminological units with characteristic unambiguity (accuracy), through the division of the text into separate fragments, through re-emphasizing key points in it, etc.

The provability (persuasiveness) of the text of scientific style is realized through a comprehensive, thorough and objective study, study of certain phenomena, processes or actions in electrical engineering, which leads to the successful receipt of the results of scientific research. Focusing on the key points of scientific research, the author tries to use facts, numerical or percentage calculations, evidence, validity of the results to influence the recipient and convince him of the above.

The conciseness (brevity) of language in the text of scientific style is realized by the author in the ability to avoid excessive detail or concretization during the description. Constant repetitions, interjections, phrases or even sentences lead to deviations from the main idea of the author and distract the recipient in the process of obtaining the necessary information.

The scientific novelty of the text of scientific style is determined by the degree of relevance and novelty of the results of scientific research, characterized by improvement: transformation, refinement or addition to existing research results or is a completely new discovery of a phenomenon, process or device in electrical engineering.

In its communicative orientation, the scientific style is focused mainly on the group and not on the individual addressee, this style is characterized by impersonality, while the addressee remains anonymous, which deprives this style of subjective emotionality. It follows that the text of the scientific style is characterized by the monologue of the presentation of the material provides semantic and structural connections between the syntactic structures of the whole text, which has a semantic and compositional completeness. The teaching of the material by the author does not involve counter-remarks. However, such a text can become the basis for dialogic speech in the discussion of the read / heard material in the text.

Having analyzed and systematized the existing concepts for defining scientific style, we take the position that scientific style can be divided into a number of substrates, which, on the one hand, are traditional, common, on the other - dependent on communicative situations, and within each subgenre certain genres function

Summary. Thus, fortheaccumulation, generalization, representation of research results of specialists in certain fields are different genres of scientific style texts, which is a means of implementing theoretical and applied scientific and technical developments. It was determined that all categories of scientific and technical text are extremely important, because only their combination models the definition of the concept of scientific and technical text.

\section{References:}

1. Азарова Л. С. Складання як один із способів словотвору : монографія. Вінниця, 2003. 123 с.

2. Акульшина Н. Лексико-семантичний спосіб словотворення військової термінології (на прикладі перської, української та англійської мов). Наукові записки. 2016. Вип. 146. С. 417-422. 
3. Алефиренко Н. Ф. Спорные проблемы семантики : монография. Москва, 2005. 326 с.

4. Андрусяк I. В. Англійські неологізми кінця XX століття як складова мовної картини світу : автореф. дис. ... канд. філол. наук : спец. 10.02.04 «Германські мови». Київ, 2003. 20 с.

5. Апресян Ю. Д. Лексическая семантика. Синонимические средства языка. Москва, 1995. 472 с.

6. Ємець О. В. Максима кількості як критерій прагмастилістичного аналізу тексту. Філологічні науки : зб. наукових праць. 2014. Вип. 18. С. 89-94.

7. Загнітко А. Лінгвістика тексту : Теорія і практикум. Донецьк, 2006. 289 с.

8. Іщенко Н. Г. Науково-технічний стиль у системі функціональних стилів. Наукові записки нащіонального університету «Острозька академія». 2014. Вип. 46. С. 78-80.

9. Мацюк 3. Мацюк 3., Станкевич Н. Українська мова професійного спілкування. Київ, 2007. 352 с.

10. Тураева 3. Я. Лингвистика текста. Москва, 1986. 127 с.

\section{Карачун Ю. Г., Борковська І. П. АНГЛОМОВНИЙ НАУКОВО-ТЕХНІЧНИЙ ТЕКСТ У РУСЛІ СУЧАСНИХ ЛІНГВІСТИЧНИХ ДОСЛІДЖЕНЬ}

Наукова стаття присвячена розгляду науково-технічного тексту сучасної англійської мови як основного засобу акумулювання, зберігання та передачі науково-технічної інформачії. Оскільки сьогодні, в епоху інформаційних технологій та наукових відкриттів, надзвичайно важллво успішно донести результати наукових досягнень до загалу, а це відбувається найчастіше через науково-технічну літературу, тому вважаємо за необхідне детальніше розглянути поняття науково-технічного тексту, зазначити основні підходи, у межах яких було розглянуто науково-технічний текст та визначити мовні й позамовні чинники, щз його формують. У процесі дослідження було з'ясовано, що науковотехнічний текст розглянуто у межах соціально-історичного, структурно-семантичного, функційносмислового, сочіокомунікативного, прагматичного та когнітивного підходів. Перший визначає текст як продукт письмової діяльності в якому відображено результати наукових досліджень спільнотами в різні епохи їхнього існування. У межах структурно-семантичного підходу текст розглянуто як послідовну семантичну єдність фраз; функиійно-смисловий характеризує текст як завершену смислову єдність, яка трунтується на семантичному та функиійному співвідношені, що існує між елементами такого тексту. Соиіокомунікативний визначає текст як продукт-посередник між комунікантами, що передає інформачію для подільного їі обговорення; у межах прагматичного підходу текст $\epsilon$ засіб впливу на отримувача інформації з урахуванням певних прагматичних чинників, а саме цільової аудиторії, її віку, їі соціального статусу, освіти тощо, а когнітивний допомагає зрозуміти текст як спосіб пізнання під впливом зазначених вище прагматичних чинників. Визначено, що саме функиійний підхід став передумовою для формування текстових категорій, серед основних виділяємо зв'язність (когезію), иілісність (когерентність), інформативність (комунікативність), членування (структурованість), завершеність, прагматичність. Серед основних мовних чинників, щяо формують науковотехнічний текст, є використання термінологічної лексики (простих, складних, складених термінів, терміносполук, термінів-метафор, скорочень абревіатур), сполучуваних елементів томо. Синтаксис представлено простими неозначено-особовими, безособовими, інфінітивними, номінативними конструкціями, складними синтагмами з різними видами зв 'язку (сурядності чи підрядності). Основними позамовними домінантами наукового стилю вважаємо однозначність (точність); логічність (послідовність) викладання матеріалу; зрозумілість (доступність); доказовість (переконливість); лаконічність (стислість); експресивність; наукову новизну, монологічний характер викладання матеріалу.

Ключові слова: науково-технічний текст, текстові категорії, мовні чинники, позамовні чинники, термін, синтаксична структура. 